\title{
Kejadian Kasus Penyakit Newcastle di Peternakan Ayam Buras di Kabupaten Barru
}

\section{(The Incidence of Newcastle Disease Amongst Backyard Chicken Farms in District of Barru)}

\author{
Winni Gusri Susanti ${ }^{1}$, Ardilasunu Wicaksono ${ }^{2}$, Chaerul Basri ${ }^{2 *}$ \\ (Diterima Maret 2020/Disetujui Mei 2021)
}

\begin{abstract}
ABSTRAK
Penyakit Newcastle Newcastle disease (ND) merupakan penyakit virus pada ayam yang sangat menular dengan tingkat kematian yang tinggi. Kerugian ekonomi yang disebabkan oleh ND adalah kematian ayam dan menurunnya produksi telur pada ayam petelur. Penelitian ini bertujuan menganalisis data distribusi penyakit dengan mengukur kecepatan penyebaran penyakit serta menggambarkan distribusi penyakit secara spasial melalui pemetaan risiko kejadian ND pada peternakan ayam buras di Kabupaten Barru. Data diperoleh dari catatan kasus ND milik dinas terkait dan wawancara menggunakan kuesioner terstruktur. Data dianalisis dengan menghitung tingkat insidensi dan menggambarkan peta risiko menggunakan sistem informasi geografi. Berdasarkan tingkat insidensi, kecepatan ratarata penyebaran ND pada ayam buras di Kabupaten Barru adalah 13 kasus per 100.000 ekor-tahun. Kejadian penyakit paling tinggi terjadi di Kecamatan Soppeng Riaja dengan tingkat insidensi 14 kasus per 100.000 ekor-tahun, sedangkan tidak ada kejadian di Kecamatan Tanete Riaja. Wilayah berisiko tinggi adalah Kecamatan Soppeng Riaja sehingga langkah-langkah pengendalian perlu lebih ditekankan di wilayah tersebut.
\end{abstract}

Kata kunci: penyakit Newcastle, tingkat insidensi, pemetaan risiko ayam buras, Kabupaten Barru

\section{ABSTRACT}

Newcastle disease (ND) is a highly contagious viral disease in chickens with a high mortality rate. The economic losses caused by the ND are the death of chickens and the decrease in egg production in laying hens. This study aims to analyze disease distribution data by measuring the rate of disease spread and describing the distribution of diseases spatially through mapping the risk of ND events at the backyard chicken farms in Barru District. The data was collected from the relevant agency's ND case records and interviews using structured questionnaires. The data was analyzed by calculating the incidence rates and describing risk maps using geographic information systems. Based on the incidence rate, the average rate of spread of ND in backyard chickens in Barru District is 13 cases per 100,000 head-ons. The highest incidence of disease occurred in Soppeng Riaja Subdistrict, with an incidence rate of 14 cases per 100,000 head of the year, while there were no incidents in Tanete Riaja Subdistrict. The high-risk area is Soppeng Riaja Subdistrict, thus, control measures need to be emphasized in this particular area.

Keywords: Newcastle disease, incidence rate, risk mapping in backyard chicken, Barru District

\section{PENDAHULUAN}

Penyakit Newcastle disease (ND) adalah penyakit yang sangat menular dengan angka kematian yang tinggi dan disebabkan oleh virus genus Paramyxovirus, famili Paramyxoviridae. ND biasa disebut juga sebagai pseudo-fowl pest, pseudovogel-pest, atypische gefugelpest, pseudo-poultry plague, avian pest, avian distemper, ranilchet disease, tetelo disease, korean fowl plague, dan avian pneumoencephalitis (AlZubeedy 2009). Penyakit ini dapat menyerang unggas,

1 Program Sarjana, Program Studi Kedokteran Hewan, Fakultas Kedokteran Hewan, Institut Pertanian Bogor, Kampus IPB Darmaga, Bogor 16680

2 Departemen IImu Penyakit Hewan dan Kesehatan Masyarakat Veteriner, Fakultas Kedokteran Hewan, Institut Pertanian Bogor, Kampus IPB Darmaga, Bogor 16680

* Penulis Korespondensi:

Email: chaerul@apps.ipb.ac.id dan ayam sangat rentan terinfeksi ND. Penyakit ND bersifat akut pada unggas serta menular secara cepat dan menimbulkan gangguan pernapasan yang sering diikuti oleh gangguan saraf serta diare (Tabbu 2000).

ND dipandang sebagai salah satu penyakit penting di bidang perunggasan. Kejadian wabah penyakit ND sering kali terjadi pada kelompok ayam yang tidak memiliki kekebalan atau kelompok yang memiliki kekebalan rendah akibat terlambat divaksinasi atau karena kegagalan program vaksinasi. Kerugian yang ditimbulkan oleh penyakit ND antara lain berupa kematian ayam, penurunan produksi telur pada ayam petelur, gangguan pertumbuhan dan penurunan bobot badan pada ayam pedaging. Kerugian akibat penyakit ND disebabkan angka kesakitan (morbiditas) dan angka kematian (mortalitas) pada ternak unggas yang sangat tinggi. Mortalitas dan morbiditas dapat mencapai $50-100 \%$ akibat infeksi virus ND strain velogenik terutama pada kelompok ayam yang peka. 
Oleh karena itu kasus ND merupakan ancaman serius bagi industri peternakan di Indonesia (Akoso 2010). Wabah ND pertama dilaporkan oleh Kraneveld di Jakarta pada tahun 1926; sejak itu penyakit dilaporkan di mana-mana dan sampai sekarang belum ada satu daerah pun di Indonesia yang bebas dari penyakit ini (Wiki ISIKHNAS 2014).

Menurut data yang diperoleh Dinas Peternakan Kabupaten Barru, populasi unggas setempat pada tahun 2015-2017 diperkirakan lebih dari 1,6 juta ekor. Berdasarkan angka populasi tersebut, 60\% merupakan populasi ayam buras (BPS 2018). Pemeliharaan ayam buras di Kabupaten Barru cukup populer dibandingkan kabupaten di Sulawesi Selatan lainnya. Hal tersebut karena pemeliharaan ayam buras ditujukan untuk menghasilkan bibit yang spesifik yang lebih banyak berfungsi sebagai hiburan atau hobi sehingga dapat mengikuti kontes perlombaan. Kasus ND pada unggas tidak termasuk penyakit prioritas oleh dinas peternakan setempat, walaupun jumlah kasusnya cukup tinggi dibandingkan penyakit lainnya sehingga perlu ditanggulangi. Berdasarkan latar belakang tersebut, perlu dianalisis kecepatan risiko kasus ND sehingga dapat dipilih metode pencegahan dan pengendalian yang tepat.

Penelitian ini bertujuan mengukur kecepatan penyebaran penyakit dan menggambarkan distribusi penyakit secara spasial melalui pemetaan risiko kejadian ND pada peternakan ayam buras di Kabupaten Barru. Penelitian ini diharapkan bermanfaat untuk mengendalikan penyakit ND, khususnya oleh Dinas Peternakan Kabupaten Barru.

\section{METODE PENELITIAN}

Data dikumpulkan pada bulan Agustus-September 2018 di Dinas Peternakan Kabupaten Barru kemudian diolah pada bulan Desember 2018-Januari 2019 di Laboratorium Epidemiologi, Divisi Kesehatan Masyarakat Veteriner dan Epidemiologi, Fakultas Kedokteran Hewan, Institut Pertanian Bogor.

Data yang digunakan dalam penelitian ini berupa data primer dan data sekunder. Data primer diambil melalui wawancara menggunakan kuesioner terstruktur dengan responden adalah dokter hewan di Dinas Peternakan Kabupaten Barru. Data dari kuesioner digunakan untuk mendukung informasi terkait dengan kejadian di lapangan. Data sekunder merupakan data yang diperoleh secara tidak langsung berupa bukti, catatan, atau laporan historis yang telah tersusun dalam arsip atau laporan dan melalui media perantara (Ruan dan Wang 2003). Populasi target adalah populasi ayam buras di Kabupaten Barru tahun 2015-2017. Kabupaten Barru memiliki 7 kecamatan. Populasi ayam buras di kabupaten ini pada tahun 2015 adalah 529.521 ekor, tahun 2016 naik menjadi 563.043 ekor, dan tahun 2017 meningkat lagi, menjadi 585.452 ekor. Data kasus positif didapatkan berdasarkan laporan kejadian kasus kematian akibat infeksi ND menggunakan sistem pelaporan iSIKHNAS tahun 2015-2017. Selain itu, data juga didasarkan pada sampel ulas (swab) trakea yang diambil dari ayam yang menunjukkan gejala klinis. Sampel tersebut diperiksa di Laboratorium Balai Besar Veteriner (BBVet) Maros menggunakan metode haemagglutination atau hemagglutination-inhibition $(\mathrm{HA} / \mathrm{HI})$ dan uji lanjutannya dengan reversetranscriptase polymerase chain reaction (RT-PCR).

Data dianalisis secara deskriptif melalui pendekatan pola spasial (ruang) dan temporal (waktu). Tingkat insidensi dihitung menggunakan bantuan aplikasi Microsoft Excel 2010 dan peta risiko penyebaran digambarkan menggunakan perangkat lunak berbasis sistem informasi geografi (GIS), yaitu perahnti lunak ArcGIS version 10.3 .

Tingkat insidensi (IR) dianalisis untuk mengevaluasi kecepatan rata-rata penyebaran penyakit (Cameron 1999), dengan menghitung jumlah kasus penyakit baru dibagi selang waktu saat setiap hewan dalam populasi berisiko terkena penyakit. Kasus baru ditentukan dengan kasus kematian ayam akibat infeksi ND dan laporan kasus positif yang telah diuji, sedangkan rataan jumlah hewan berisiko ditentukan dengan metode perkiraan, yaitu rataan dari jumlah individu berisiko pada awal pengamatan ditambah dengan jumlah individu berisiko pada akhir pengamatan (Rothman et al. 2008). Hal ini dirumuskan sebagai berikut:

$\mathrm{IR}=$ Jumlah kasus baru penyakit dalam kurun tertentu

\section{Rataan jumlah hewan berisiko $\times$ kurun waktu}

Data insidensi kasus selanjutnya dikategorikan menjadi 4 tingkatan, yaitu diabaikan, rendah, sedang, dan tinggi. IR dikategorikan dengan cara membagi data insidensi tertinggi di daerah penelitian menjadi 4 tingkat secara merata. Berdasarkan perhitungan tersebut, daerah tanpa kasus dinilai sebagai diabaikan, jumlah 1-20 kasus dinilai rendah, 21-60 kasus dinilai sedang, dan 61-100 dinilai tinggi.

Matriks analisis risiko (diadaptasi dari WHO rapid risk assessment guideline) digunakan untuk menilai risiko penyebaran penyakit berdasarkan kategori IR. Matriks analisis risiko kualitatif yang digunakan untuk menilai risiko penyebaran penyakit dapat dilihat pada Tabel 1. Berdasarkan matriks tersebut, nilai risiko akhir didapatkan dengan cara mengalikan risiko penyebaran penyakit pada tahun yang berbeda. Risiko akhir penyebaran ND didapatkan dari pengalian nilai risiko penyebaran ND pada tahun 2015, 2016, dan 2017. Rumus untuk penentuan risiko penyebaran ND diformulasikan sebagai berikut:

$$
\text { Risiko akhir }=\left(\mathrm{Ct}_{1} \times \mathrm{Ct}_{2}\right) \times \mathrm{Ct}_{3}
$$

\footnotetext{
Keterangan:

$\mathrm{Ct}_{1}=$ Kategori kasus tahun 2015

$\mathrm{Ct}_{2}=$ Kategori kasus tahun 2016

$\mathrm{Ct}_{3}=$ Kategori kasus tahun 2017
} 


\section{HASIL DAN PEMBAHASAN}

\section{Keadaan Peternakan dan Sarana Kesehatan Hewan}

Penyebaran penyakit di peternakan sering dikaitkan dengan pola manajemen pemeliharaan yang buruk atau penanganan yang terlambat sehingga menyebar di beberapa wilayah dan berakibat fatal. Partisipasi masyarakat dalam melaporkan kasus juga termasuk salah satu upaya guna mencegah penyebaran penyakit. Manajemen pemeliharaan dan sistem pelaporan ayam buras Kabupaten Barru berdasarkan data kuesioner dapat dilihat pada Tabel 2.

Sistem pemeliharaan secara diumbar (tradisional) masih banyak ditemui di lingkungan pedesaan Kabupaten Barru. Hampir setiap keluarga di sini memiliki 2-5 ayam buras yang diumbar di halaman rumah. Hal tersebut menyebabkan tingginya kontak langsung antar-ayam dan sulitnya mencegah infeksi ND. Sistem pemeliharaan secara diumbar merupakan cara pemeliharaan yang sangat sederhana, tidak memerlukan banyak input terutama pakan, dan ayam mencari sendiri pakannya dari lahan umbaran (Pramudyati 2009). Kelemahan sistem ini adalah keamanan dari predator dan penyakit akibat kontak dengan ayam lainnya. Sistem ini cukup menguntungkan apabila tidak terjadi serangan penyakit (Iskandar 2010). Umumnya, ayam buras di Kabupaten Barru berasal dari daerah setempat dan tidak mendatangkan bibit dari luar. Pemeliharaan secara diumbar dan asal ayam dari daerah setempat menyebabkan penyebaran kasus ND semakin cepat karena tingginya kontak langsung antarayam dan sulit melakukan disinfeksi.

Sejak tahun 2014, Kabupaten Barru menjadi projek percontohan untuk sistem informasi kesehatan nasional (iSIKHNAS) dan menjadi kabupaten pertama yang memakai sistem pelaporan tersebut di Sulawesi. iSIKHNAS adalah sistem informasi kesehatan hewan Indonesia yang memudahkan pemerintah mengumpulkan data ternak dari lapangan dan segera menyediakannya kepada masyarakat yang membutuhkan (Wiki iSIKHNAS 2014). Peternak yang menemukan gejala klinis ND akan segera melaporkan kepada dinas setempat. Dinas setempat melakukan koordinasi dengan petugas lapangan untuk menanggulangi. Kasus ND pada ayam buras dalam iSIKHNAS termasuk penyakit yang tingkat mortalitasnya tinggi.

Kecepatan tanggap penyakit tersebut memerlukan sumber daya manusia (SDM) dan sarana kesehatan hewan (keswan) yang memadai. SDM dan sarana keswan Kabupaten Barru dapat dilihat pada Tabel 3.

Dinas Kabupaten Barru memiliki 2 orang dokter hewan dan 8 orang paramedik yang tersebar di beberapa wilayah, serta memiliki 2 unit pusat keswan, yakni di Kecamatan Barru dan di Kecamatan Tanete Rilau. Menurut Permentan No. 64/2007, SDM yang bertugas di pusat keswan sekurang-kurangnya terdiri atas 1 dokter hewan, 2 paramedik veteriner, 4 teknisi pusat keswan (asisten teknis reproduksi, petugas pemeriksa kebuntingan, inseminator, dan vaksinator). Puskeswan memiliki sarana transportasi satu unit kendaraan roda empat untuk puskeswan keliling.

Tabel 1 Matriks analisis risiko secara kualitatif (diadaptasi dari world health organization (WHO) rapid risk assessment guideline)

\begin{tabular}{lllll}
\hline & Diabaikan & Rendah & Sedang & Tinggi \\
\hline Diabaikan & Diabaikan & Rendah & Rendah & Sedang \\
Rendah & Rendah & Sedang & Sedang & Sedang \\
Sedang & Rendah & Sedang & Tinggi & Tinggi \\
Tinggi & Sedang & Sedang & Tinggi & Tinggi \\
\hline
\end{tabular}

Tabel 2 Manajemen pemeliharaan dan sistem pelaporan ayam buras

\begin{tabular}{|c|c|c|c|}
\hline Pertanyaan & $\mathrm{Ya}$ & Tidak & Keterangan \\
\hline Tipe kandang pemeliharaan & & & Diumbar (dilepas) \\
\hline Asal ayam buras & & & Daerah setempat \\
\hline Sistem iSIKHNAS & $\checkmark$ & & Sistem iSIKHNAS dijalankan sejak 2014 \\
\hline $\begin{array}{l}\text { Penyakit ND masuk ke pelaporan } \\
\text { iSIKHNAS }\end{array}$ & $\checkmark$ & & \\
\hline $\begin{array}{l}\text { Respons Dinas saat mendapat pelaporan } \\
\text { kasus }\end{array}$ & $\checkmark$ & & $\begin{array}{l}\text { Segera berkoordinasi sesama petugas teknis, } \\
\text { dilanjutkan dengan pengobatan }\end{array}$ \\
\hline $\begin{array}{l}\text { Petugas yang merespons pelaporan } \\
\text { kasus }\end{array}$ & & & Dokter hewan dan paramedik \\
\hline
\end{tabular}

Tabel 3 Sumber daya manusia dan sarana keswan

\begin{tabular}{|c|c|c|c|}
\hline SDM/sarana & Ada & Tidak ada & Keterangan \\
\hline Dokter hewan & $\checkmark$ & & 2 orang \\
\hline Paramedik & $\checkmark$ & & 8 orang \\
\hline Puskeswan & $\checkmark$ & & 2 unit \\
\hline Laboratorium & & $\checkmark$ & BBVet Maros \\
\hline Petugas lapangan terlatih & $\checkmark$ & & Tersebar di seluruh kecamatan \\
\hline Kendaraan operasional & $\checkmark$ & & \\
\hline
\end{tabular}


Kurangnya sarana keswan menyebabkan lambatnya respons petugas atas kasus ini, sehingga semakin cepat penyebaran kasus ND di wilayah tersebut.

\section{Kasus ND pada Ayam Buras}

Rekap data kasus ND pada ayam buras per kecamatan berdasarkan pelaporan pasif kepada Dinas Peternakan Kabupaten Barru dapat dilihat pada Tabel 4. Jumlah kasus ND di Kabupaten Barru dalam kurun waktu 3 tahun tercatat 121 kasus. Jumlah kasus tersebut di setiap kecamatan meningkat dan menurun secara fluktuatif setiap tahun. Kejadian ND terendah ditemukan di Kecamatan Tanete Riaja dan kejadian tertinggi di Kecamatan Soppeng Riaja. Menurut Wibowo et al. (2012), beberapa hal yang menjadi penyebab munculnya kasus ND antara lain masalah manajemen peternakan, kualitas vaksin, serta variasi patotipe virus yang beredar di lapangan. Kecamatan Tanete Riaja tidak memiliki petugas medis dan sarana keswan sehingga kejadian kasus ND dan kecamatan ini belum dapat terdeteksi oleh petugas dinas. Hal inilah yang menyebabkan tidak ada kasus yang tercatat di wilayah tersebut.

Tinggi rendahnya kasus dipengaruhi oleh kecepatan penyebaran kasus ND dan pekanya petugas lapangan maupun peternak dalam melihat gejala klinis dari ayam yang sakit. Cara diagnosis kasus ND di Kabupaten Barru dapat dilihat pada Tabel 5. Gejala penyakit ND yang dapat diamati antara lain sesak napas, batuk, lemah, nafsu makan menurun, diare, dan bergerombol. Gejala saraf juga teramati dengan jelas, yaitu paralisis total atau parsial seperti tremor atau kejang otot, bergerak melingkar, dan jatuh dengan sayap terkulai dan leher terputar (torticolis) (Kencana \& Kardena 2011). Menurut petugas lapangan, gejala klinis yang teramati adalah ngorok, feses hijau, mengeluarkan leleran (discharge), dan kematian yang tinggi. Dinas menetapkan kasus positif ND jika sudah teruji dalam pemeriksaan laboratorium di BBVet Maros.

\section{Tingkat Insidensi ND}

Kecepatan kejadian ND dapat diukur dalam tingkat insidensi. Hasil perhitungan tingkat insidensi ND di Kabupaten Barru per kecamatan dapat dilihat pada Tabel 6. Tingkat insidensi tertinggi selama 3 tahun terjadi di Kecamatan Soppeng Riaja, yaitu 14 kasus per 100.000 ekor-tahun. Kecamatan Balusu dan Mallusetasi memiliki tingkat insidensi yang sama, yaitu 3 kasus per 100.000 ekor-tahun. Tingginya angka

Tabel 4 Jumlah Kasus Newcastle disease (ND) pada peternakan ayam buras per kecamatan

\begin{tabular}{lcccc}
\hline \multirow{2}{*}{ Kecamatan } & \multicolumn{3}{c}{ Jumlah kasus ND (peternakan) } & \multirow{2}{*}{ Jumlah } \\
\cline { 2 - 4 } & Tahun 2015 & Tahun 2016 & Tahun 2017 & 5 \\
Pujananting & 0 & 0 & 5 & 0 \\
Tanete Riaja & 0 & 0 & 7 & 9 \\
Tanete Rilau & 0 & 2 & 0 & 10 \\
Barru & 10 & 0 & 0 & 72 \\
Balusu & 17 & 0 & 55 & 8 \\
Soppeng Riaja & 17 & 0 & 0 & 17 \\
Mallusetasi & 0 & 8 & 60 & 121 \\
\hline Total & 44 & 10 & & \\
\hline
\end{tabular}

Tabel 5 Diagnosis kasus Newcastle disease (ND)

\begin{tabular}{lcll}
\hline \multicolumn{1}{c}{ Pertanyaan } & Ya & Tidak & \multicolumn{1}{c}{ Keterangan } \\
\hline Petugas yang turun ke lapangan untuk & $\checkmark$ & $\begin{array}{l}\text { Dokter hewan, paramedik, petugas } \\
\text { lapangan terlatih }\end{array}$ \\
Kasus positif: & & \\
Pelaporan & $\checkmark$ & \\
Gejala klinis & $\checkmark$ & Dilakukan oleh BBVET Maros \\
Laboratorium & $\checkmark$ & $\checkmark$ & \\
Pemeriksaan laboratorium lanjutan & $\checkmark$ &
\end{tabular}

Tabel 6 Tingkat insidensi Newcastle disease (ND) di Kabupaten Barru per kecamatan

\begin{tabular}{lccc}
\hline \multicolumn{1}{c}{ Kecamatan } & Rataan populasi berisiko & $\begin{array}{c}\text { Tingkat insidensi } \\
\text { (kasus/ekor-3 tahun) }\end{array}$ & $\begin{array}{c}\text { Tingkat insidensi } \\
\text { (kasus/100000 ekor-tahun) }\end{array}$ \\
\hline Pujananting & 268477 & $0,62 \times 10^{-5}$ & 1 \\
Tanete Riaja & 0 & $0,00 \times 10^{-5}$ & 0 \\
Tanete Rilau & 318815 & $0,94 \times 10^{-5}$ & 1 \\
Barru & 335594 & $0,99 \times 10^{-5}$ & 1 \\
Balusu & 201352 & $2,81 \times 10^{-5}$ & 3 \\
Soppeng Riaja & 167763 & $14,3 \times 10^{-5}$ & 14 \\
Mallusetasi & 100676 & $2,64 \times 10^{-5}$ & 3 \\
Mallusetasi & 100676 & $2,64 \times 10^{-5}$ & 3 \\
\hline
\end{tabular}


populasi pemeliharaan ayam buras di kabupaten ini menyebabkan kontak langsung antarayam semakin tinggi sehingga memengaruhi kecepatan penyebaran kasus. Pemeliharaan secara diumbar memungkinkan terjadinya kontak langsung antarayam dan sulit mendisinfeksi secara optimum (Pramudyati 2009). Tingkat insidensi terendah selama 3 tahun adalah di Kecamatan Tanete Riaja, yakni 0 kasus. Sistem pelaporan iSIKHNAS di Kabupaten Barru masih terpusat pada laporan oleh petugas lapangan. Namun kurangnya pengetahuan peternak mengenai sistem pelaporan iSIKHNAS menyebabkan banyak kasus yang terjadi tidak tercatat. Selain itu, keadaan geografis Kecamatan Tanete Riaja yang didominasi oleh pegunungan yang menyebabkan sukarnya petugas lapangan menjangkau perdesaan.

Hasil perhitungan tingkat insidensi ND di Kabupaten Barru per tahun dapat dilihat pada Tabel 7. Nilai tingkat insidensi kasus ND dalam kurun waktu 3 tahun ialah 13 kasus per 100000 ekor/tahun. Tingkat insidensi di setiap tahun berfluktuasi. Tingkat insidensi terendah terjadi pada tahun 2016 sedangkan tingkat insidensi tertinggi pada tahun 2017. Hal ini berbanding lurus dengan jumlah kasus yang diperoleh setiap tahun. Menurut Wiedosari \& Wahyuwardani (2015), perubahan cuaca ekstrem menyebabkan ayam stres dan mudah terserang penyakit sehingga penyebaran ND semakin cepat.

Tingginya kecepatan kasus yang terjadi setiap tahun membuat dinas semakin berupaya untuk menanggulangi dan mencegah penyebaran penyakit di seluruh wilayah. Upaya pencegahan dan pengendalian kasus ND oleh Dinas Kabupaten Barru dapat dilihat pada Tabel 8. Ayam sakit akan diisolasi pada kandang khusus dan diberi obat. Sediaan obat yang diberikan berupa Medoxy- $L^{\circledR}$, Limoxyn $50^{\circledR}$, dan vitamin. Pengobatan tersebut tidak diberikan gratis oleh pemerintah. Medoxy- $\mathrm{L}^{\circledR}$ bekerja terhadap sebagian besar bakteri Gram positif dan Gram negatif, termasuk yang resisten terhadap penisilin (Medion 2009). Limoxyn $50^{\circledR}$ termasuk dalam kelompok tetrasiklin dan bertindak bakteriostatik terhadap banyak bakteri Gram positif dan Gram negatif (Iskandar 2012).

Program vaksinasi ND ayam buras dijalankan secara rutin oleh dinas menggunakan Medivac ND-Al ${ }^{\circledR}$. Medivac ND-A ${ }^{\circledR}$ mengandung virus ND galur $L a$ Sota dan Al subtipe $H 5$, yang telah diinaktifkan dan diemulsikan ke dalam adjuvan minyak mineral untuk meningkatkan dan memperpanjang daya kerja vaksin (Kencana \& Yuniati 2016). Menurut petugas lapangan, kegiatan booster vaksinasi tidak dapat dilakukan karena sulit menangkap ayam yang diumbar serta tidak ada catatan riwayat vaksinasi setiap ayam.

Sistem pemeliharaan yang diumbar menyebabkan tidak terkedalinya kebersihan lingkungan hidup ayam buras. Masyarakat hanya melakukan disinfeksi saat ayam mati akibat infeksi ND. Virus ND mampu bertahan hidup hingga 2 bulan di dalam tumpukan sekam kering yang digunakan sebagai alas kandang (Wiedosari \& Wahyuwardani 2015). Disinfeksi lingkungan sebaiknya digiatkan setiap pekan untuk mematikan virus ND atau agen penyakit lainnya. Menurut Santhia (2003), tindakan pengendalian sangat diperlukan terutama dalam hal disinfeksi dan sanitasi secara rutin. Penanggulangan kasus ini membutuhkan kerja sama antara masyarakat dan dinas, tetapi partisipasi dan pengetahuan masyarakat terhadap kasus ini masih kurang.

\section{Peta Risiko Penyebaran ND}

Kategori kasus di setiap kecamatan dikelompokkan berdasarkan tingkat insidensi. Risiko akhir merupakan hasil perpaduan kategori kasus selama 3 tahun. Tabel risiko penyebaran ND dapat dilihat pada Tabel 9. Berdasarkan hasil pemetaan menggunakan GIS, peta risiko penyebaran kasus ND di Kabupaten Barru dapat

Tabel 7 Tingkat insidensi kasus Newcastle disease (ND) di Kabupaten Barru per tahun

\begin{tabular}{lrrrr}
\hline \multicolumn{1}{c}{ Tahun } & Kasus & $\begin{array}{c}\text { Rataan populasi } \\
\text { berisiko }\end{array}$ & IR (Kasus/ekor-tahun) & IR (Kasus/100000 ekor-tahun) \\
\hline 2015 & 44 & 642987 & $6,8 \times 10^{-5}$ & 7 \\
2016 & 10 & 643477 & $1,6 \times 10^{-5}$ & 2 \\
2017 & 67 & 710902 & $9,4 \times 10^{-5}$ & 10 \\
Jumlah (3 tahun) & 121 & 1997366 & $13 \times 10^{-5}$ & 13 \\
\hline
\end{tabular}

Keterangan: IR = Tingkat insidensi.

Tabel 8 Pencegahan dan pengendalian penyakit

\begin{tabular}{|c|c|c|c|}
\hline Pertanyaan & $\mathrm{Ya}$ & Tidak & Keterangan \\
\hline Monitoring khusus & $\checkmark$ & & \\
\hline Isolasi ayam sakit & $\checkmark$ & & \\
\hline Pengobatan & $\checkmark$ & & Medoxy-L ${ }^{\circledR}$, Limoxyn $50^{\circledR}$, vitamin \\
\hline Program vaksinasi Newcastle disease & $\checkmark$ & & Sediaan Medivac ND-Al ${ }^{\circledR}$ \\
\hline $\begin{array}{l}\text { Pemeriksaan khusus ayam buras yang baru } \\
\text { datang }\end{array}$ & $\checkmark$ & & Pemeriksaan gejala klinis \\
\hline Sosialisasi/penyuluhan & $\checkmark$ & & \\
\hline Disinfeksi rutin & & $\checkmark$ & \\
\hline Pengawasan lalu lintas & $\checkmark$ & & \\
\hline
\end{tabular}


Tabel 9 Kategori hasil risiko penyebaran Newcastle disease (ND) di Kabupaten Barru

\begin{tabular}{|c|c|c|c|c|c|c|c|}
\hline \multirow{2}{*}{ Kecamatan } & \multicolumn{2}{|c|}{2015} & \multicolumn{2}{|c|}{2016} & \multicolumn{2}{|c|}{2017} & \multirow{2}{*}{ Risiko } \\
\hline & IR & $\mathrm{Ct}_{1}$ & IR & $\mathrm{Ct}_{2}$ & IR & $\mathrm{Ct}_{3}$ & \\
\hline Pujananting & 0 & $\mathrm{~N}$ & 0 & $\mathrm{~N}$ & 5,33 & $\mathrm{R}$ & $\mathrm{R}$ \\
\hline Tanete Riaja & 0 & $\mathrm{~N}$ & 0 & $\mathrm{~N}$ & 0 & $\mathrm{~N}$ & $\mathrm{~N}$ \\
\hline Tanete Rilau & 0 & $\mathrm{~N}$ & 1,86 & $\mathrm{R}$ & 6,29 & $\mathrm{R}$ & $\mathrm{S}$ \\
\hline Barru & 9,44 & $\mathrm{R}$ & 0 & $\mathrm{~N}$ & 0 & $\mathrm{~N}$ & $\mathrm{R}$ \\
\hline Balusu & 26,75 & S & 0 & $\mathrm{~N}$ & 0 & $\mathrm{~N}$ & $\mathrm{R}$ \\
\hline Soppeng Riaja & 32,10 & $S$ & 0 & $\mathrm{~N}$ & 93,99 & $\mathrm{~T}$ & $\mathrm{~T}$ \\
\hline Mallusetasi & 0 & $\mathrm{~N}$ & 23,68 & S & 0 & $\mathrm{~N}$ & $\mathrm{R}$ \\
\hline
\end{tabular}

Keterangan: IR (tingkat insidensi) (per 100000 ekor), $\mathrm{Ct}_{1}$ (kategori kasus tahun 2015), $\mathrm{Ct}_{2}$ (kategori kasus tahun 2016$), \mathrm{Ct}_{3}$ (kategori kasus tahun 2017), diabaikan/tidak ada kasus $(\mathrm{N})\left(0 \times 10^{-5}\right)$, rendah $(\mathrm{R})\left((1-20) \times 10^{-5}\right)$, sedang (S) $\left.(21-60) \times 10^{-5}\right)$, tinggi $\left.(\mathrm{T})(61-100) \times 10^{-5}\right)$.

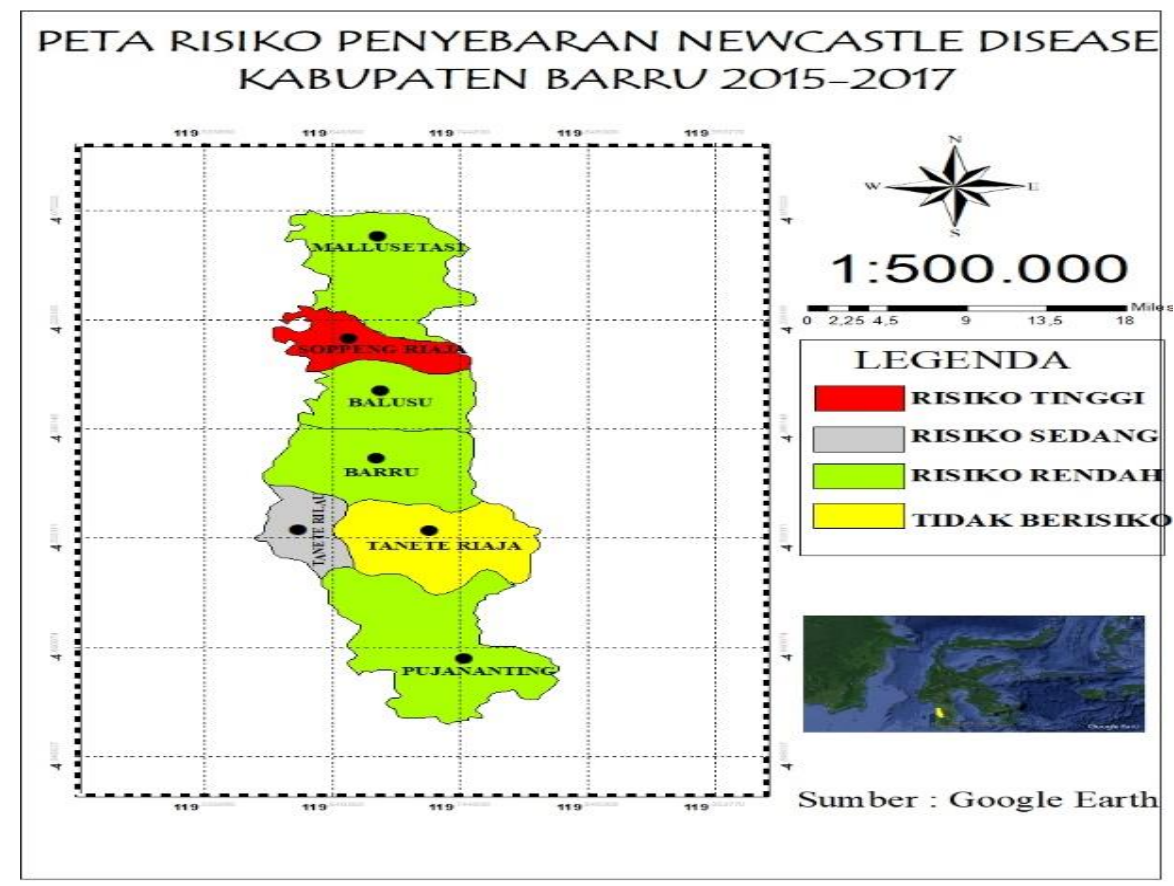

Gambar 1 Peta sebaran kasus ND pada ayam buras di Kabupaten Barru.

dilihat pada Gambar 1. Wilayah yang tidak berisiko (tidak ada kasus), ditandai dengan warna kuning, yaitu Kecamatan Tanete Riaja. Wilayah yang termasuk risiko rendah, ditandai dengan warna hijau, yaitu Kecamatan Pujananting, Barru, Balusu, Mallusetasi. Wilayah yang berisiko sedang, ditandai dengan warna abu-abu, yaitu Kecamatan Tanete Rilau. Wilayah risiko tinggi yang ditandai dengan warna merah, yaitu Kecamatan Soppeng Riaja. Pengawasan lalu lintas sangat diperlukan terutama pada wilayah dengan risiko tinggi (Santhia 2003). Wilayah risiko rendah dapat berpotensi menjadi risiko tinggi jika pengawasan lalu lintas dan pengendalian tidak segera dilaksanakan.

Kasus ND dapat dicegah dengan pengawasan khusus pada ayam yang baru datang dengan cara memeriksa kelengkapan surat keterangan kesehatan hewan (SKKH) dan melakukan check point (pemeriksaan hewan), serta pengamatan gejala klinis secara tepat atas penyakit yang menyerang unggas.

\section{KESIMPULAN}

Pengendalian kasus ND di Kabupaten Barru belum berhasil mengurangi kecepatan penyebaran penyakit. Kecepatan penyebaran ditunjukkan dengan nilai tingkat insidensi sebesar 13 kasus per 100.000 ekor/tahun. Tingkat insidensi tertinggi selama 3 tahun adalah di Kecamatan Soppeng Riaja, 14 kasus per 100.000 ekor/tahun, sedangkan tingkat insidensi terendah selama 3 tahun adalah di Kecamatan Tanete Riaja, 0 kasus. Kecamatan dengan risiko tinggi adalah di Kecamatan Soppeng Riaja.

\section{DAFTAR PUSTAKA}

Akoso BT. 2010. Manual Kesehatan Unggas. Yogyakarta (ID): Kanisius. 
Al-Zubeedy AZ. 2009. Immune respons in day old broiler chicks vaccinated against newcastle disease virus. Iraqi Journal Veteriner Science. 23(2): 143-146.

[BPS] Badan Pusat Statistik. 2018. Statistik Daerah Provinsi Sulawesi Selatan 2018. Sulawesi Selatan (ID): Badan Pusat Statistik Provinsi Sulawesi Selatan. Hal 148-157.

Cameron, A.R. 1999. Survey Toolbox for Livestock Diseases - A Practical Manual and Software Package for Active Surveillance in Developing Countries. ACIAR. Hal 28.

Iskandar J. 2012. Pedoman Praktis Obat Indonesia. Jakarta (ID): PT Bhuana IImu Populer.

Iskandar S. 2010. Usaha Tani Ayam Kampung. Bogor (ID): Balai Penelitian Ternak Ciawi.

Kementerian Pertanian. 2008. Peraturan Menteri Pertanian Nomor 64/Permentan/OT.140/9/2007 Tentang Pedoman Pelayanan Pusat Kesehatan Hewan. Jakarta (ID): Balitbang Pertanian.

Kencana GAY dan Kardena IM. 2011. Gross pathological observation of acute Newcastle disease in domestic chicken. Prosiding Seminar Internasional Perhimpunan Mikrobiologi Indonesia (PERMI) dan International Union of Microbiological Societies (IUMS); 2011 Jun 22-24; Denpasar (ID).

Kencana GAY dan Yuniati GA. 2016. Vaksin kombinasi newcastle disease dengan avian influenza memicu imunitas protektif pada ayam petelur terhadap penyakit tetelo dan flu. Jurnal Veteriner. 17(2):257264. https://doi.org/10.19087/jveteriner.
Medion. 2009. Sediaan obat obat antibiotik [internet]. [diakses 2018 Okt 16]. Tersedia dari: https://info.medion.co.id/index.php/lainlain?catid=0\&id=105.

Pramudyati SP. 2009. Petunjuk Teknis Beternak Ayam Buras. Sumatera Selatan (ID): BPTP. Hal 144-168.

Rothman KJ, Greenland S, Lash TL. 2008. Modern Epidemiologi. Philadelphia (USA): Lippincott Williams \& Wilkins.

Ruan S dan Wang W. 2003. Dynamical behavior of an epidemic model with a nonlinear incidence rate. Journal of differential equations. 188(1): 135-163. https://doi.org/10.1016/S0022-0396(02)00089-X

Santhia K. 2003. Strategi diagnosa dan penanggulangan newcastle disease. Prosiding Seminar Regional Perunggasan; 2003 Okt 6; Denpasar, Indonesia.

Tabbu CR. 2000. Penyakit Ayam dan Penanggulangannya: Penyakit Bakterial, Mikal, dan Viral. Yogyakarta (ID): Kanisius.

Wibowo MH, Untari T, Wahyuni AETH. 2012. Isolasi, identifikasi, sifat fisik, dan biologi virus tetelo yang diisolasi dari kasus di lapangan. Jurnal Veteriner. 13(4): 425-433.

Wiedosari E dan Wahyuwardani S. 2015. Studi kasus penyakit ayam pedaging di Kabupaten Sukabumi dan Bogor. Jurnal Kedokteran Hewan. 9(1): 8-13. https://doi.org/10.21157/j.ked.hewan.v9i1.2777

Wiki ISIKHNAS. 2014. Pengertian ISIKHNAS [internet]. [diakses 2018 Okt 14]. Tersedia pada: http://www.wikilSIKHNAS.com/. 